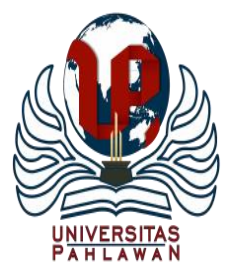

Edukatif : Jurnal Ilmu Pendidikan Volume 3 Nomor 4 Tahun 2021 Halm 1543 - 1549

EDUKATIF: JURNAL ILMU PENDIDIKAN

Research \& Learning in Education

https://edukatif.org/index.php/edukatif/index

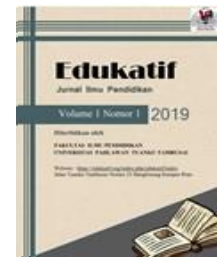

\title{
Perilaku Dan Pengembangan Organisasi Pendidikan Review Disain Intervensi
}

\author{
Ulil Amri ${ }^{1 凶}$ Hendri $^{2}$, Rusdinal $^{3}$, Nurhizrah Gistituati $^{4}$ \\ Universitas Negeri Padang, Indonesia ${ }^{1,2,3,4}$ \\ E-mail : ulilamri845@gmail.com ${ }^{1}, \underline{\text { hendri@ } @ \text { mpd.com }}^{2}$, rusdinal@ fip.unp.ac.id $^{3}$, \\ gistituatinurhizrah@gmail.com ${ }^{4}$
}

\begin{abstract}
Abstrak
Pengembangan organisasi merupakan suatu proses perubahan atau intervensi. Hal ini dimulai dari perubahan struktur dan sistem di dalam sebuah organisasi. Intervensi dilakukan sebagai upaya pengembangan sebuah yang bertujuan untuk meningkatkan keefektian kerja sebuah organisasi. Dengan demikian tujuan dari penelitian ini adalah untuk mengetahui tentang bagaimana disain intervensi dalam upaya untuk pengembangan organisasi pendidikan. Metode yang digunakan dalam penulisan artikel ini adalah literature review atau tinjauan pustaka. Dengan melakukan evaluasi dan kajian dari penelitian-penelitian sebelumnya Hasil dari penelitian ini adalah dalam prakterknya pengembangan organisasi menggunakan teknik intervensi yang terencana terhadap proses dalam organisasi dengan memanfaatkan teori-teori perilaku organisasi. Intervensi ini dilakukan dalam rangka menanta dan memperbaiki kembali fungsi organsiasi untuk berkerja dalam tim ataupun mereka mengelola suatu tim serta memelihara organisasi agar tetap dapat berjalan dengan baik sesuai dengan tujuan organisasi. Sebuah intervensi merupakan suatu rangkaian kegiatan dalam perubahan terencana yang ditujukan untuk mendorongan peningkatan efektivitas sebuah organsiasi.
\end{abstract}

Kata Kunci: Prilaku, Pengembangan, Organisasi, Disain, Intervensi

\begin{abstract}
Organizational development is a process of change or intervention. This starts from changes in the structure and systems within an organization. The intervention is carried out as an effort to develop an organization that aims to increase the effectiveness of an organization's work. Thus the purpose of this study is to find out how to design interventions in an effort to develop educational organizations. The method used in writing this article is a literature review or literature review. By evaluating and reviewing previous studies. The results of this research are in the practice of organizational development using planned intervention techniques on processes in organizations by utilizing theories of organizational behavior. This intervention is carried out in order to maintain and improve organizational functions to work in teams or manage a team and maintain the organization so that it can continue to run well following organizational goals. An intervention is a series of activities in a planned change aimed at increasing the effectiveness of an organization.
\end{abstract}

Keywords: Behavior, Development, Organization, Design, Intervention

Copyright (c) 2021 Ulil Amri, Hendri, Rusdinal, Nurhizrah Gistituati

$\triangle$ Corresponding author:

Email : ulilamri845@gmail.com

DOI $\quad:$ https://doi.org/10.31004/edukatif.v3i4.605

ISSN 2656-8063 (Media Cetak)

ISSN 2656-8071 (Media Online)

Edukatif : Jurnal Ilmu Pendidikan Vol 3 No 4 Tahun 2021 p-ISSN 2656-8063 e-ISSN 2656-8071 
1544 Perilaku Dan Pengembangan Organisasi Pendidikan Review Disain Intervensi - Ulil Amri, Hendri, Rusdinal, Nurhizrah Gistituati

DOI: https://doi.org/10.31004/edukatif.v3i4.605

\section{PENDAHULUAN}

Intervensi merupakan suatu kegiatan perbaikan yang terencana dalam proses pembinaan organisasi. Argyris merumuskan agak lebih terinci. "intervensi merupakan kegiatan yang mencoba masuk kedalam suatu sistem tata hubungan yang sedang berjalan, hadir berada diantara orang-orang, kelompok ataupun suatu objek dengan tujuan untuk membantu mereka".(Rifqi Muntaqo 2017) Ada suatu pemikiran yang implisit dari pengertian Argyris itu yang harus dibuat eksplisit. Pemikiran itu ialah bahwa sistem yang akan diintervensi itu tidak tergantung sama sekali pada pengintervensi. Dari sisi manajemen organisasi adalah sebuah sistem lain atau suatu sarana yang menerima input manajemen berupa tujuan-tujuan dan sasaran yang ingin dicapai dan outputnya diharapkan berupa realisasi yang sesuai dengan rencana tersebut. Dalam sistem organisasi maka yang jadi tujuan adalah bagaimana agar tercipta kerjasama diantara personil yang terkait dalam struktur organisasi itu.

Dalam berbagai penelitian terdahulu seperti penelitian yang dilakukan oleh Ahmad Misbahul Anam, dijelaskan bahwa dalam usaha untuk menumbuhkan partisipasi dalam sebuah lambaga pendidikan, sangat dibutuhkan sekali sentuhan intervensi dari lembaga dan unit-kerja (Anam 2018). Pengembangan organisasi merupakan suatu sarana dalam upaya mencapai tujuan sebuah organisasi. Suatu organisasi dapat menyesuaikan diri dengan perkembangan zaman. Sasaran pengembangan organsiasi mengarah pada hubungan pribadi yang lebih efetif antara manajer dan karyawan di semua jenjang organisasi guna menghilangkan semua hambatan komunikasi yang terjadi baik komunikasi antarpribadi ataupun kelompok. Dalam prakteknyapengembangan organasisi membutuhkan teknik intervensi yang terencana dengan memanfaatkan teori-teori prilaku organisasi. (Pramudyo n.d.)

Pengembangan organisasi bertujuan untuk meningkatkan keefektifan kerja organisasi. Duha (2016) mendefinisikan Pengembangan organisasi sebagai sebuah proses yang berkesinambungan secara terusmenerus yang dilakukan untuk melakukan usaha-usaha perbaikan atas berbagai kegagalan dan kesalahan, juga untuk memenuhi berbagai harapan-harapan yang diinginkan, serta bagian dari cara untuk peningkatan (kualitas, kuantitas) yang telah dimiliki sebelumnya, dengan mempertahankan nilai-nilai dasar dan utama yang terkandung di dalam budaya organisasi. Dalam prakteknya pengembangan organisasi adalah menggunakan teknik intervensi yang terencana terhadap proses dalam organisasi, dengan memanfaatkan teori-teori prilaku organisasi(Latar n.d.). Intervensi pengembangan organisisi ini dilakukan oleh seorang manager ataupun konsultan, atau anggota dengan sasaran individu, kelompok, dan organisasi. Intervensi dalam artian memilihkan satu keputsan setelah terjadinya proses interaksi kritis dan dinamis, atau dalam sebutan lainnya adalah kesimpulan alternatfi dan konsekwensi kegiatan, bukan intervensi kekuasaan dalam ilmu politik praktis (Anam, 2018). Hal sejalan juga ditemukan pada penelitian Johandri Taufan, Rika Maria, Rusdinal Rusdinal (2021) intervensi yang dilaksanakan adalah dalam rangka terwujudnya komitmen yang tinggi dari seluruh warga madrasah dan stakeholders terhadap pencapaian tujuan yang diharapkan, meningkatnya kemampuan guru untuk melaksanakan pengajaran yang efektif dan terstruktur, dan tercapainya mutu lulusan yang diharapkan.

Menurut Wijaya, (2017) sebuah organisasi harus mengalami perubahan, demi untuk ketercapaian tujuan organisasi dan juga untuk mempertahankan eksistensi dari organisasi itu sendiri. Perubahan bagi organisasi dimana manusia yang berada di dalamnya dilakukan oleh manusia, manusia tersebutlah yang menginginkan terjadinya perubahan dalam organisasi sehingga organisasi melalui kesepakatan bersama anggota-anggota dapat mencapai tujuan tersebut. Perubahan dalam organisasi bukan semata untuk kepentingan organisasi, tetapi justru yang lebih berkepentingan adalah manusia yang ada dalam organisasi.

Berdasarkan penjelasan di atas, maka yang menjadi tujuan dari penulisan ini adalah untuk mengetahui apa yang dimaksud dengan intervensi pengembangan organisasi, memahami tentang klasifikasi intervensi, memahami bagaimana merencang intervensi, serta memahami bagaimanakah intervensi yang efektif tersebut. 
1545 Perilaku Dan Pengembangan Organisasi Pendidikan Review Disain Intervensi - Ulil Amri, Hendri, Rusdinal, Nurhizrah Gistituati

DOI: https://doi.org/10.31004/edukatif.v3i4.605

Penelitian merupakan penelitian yang penulis lakukan sendiri, dengan terlebih dahulu memperhatikan konsepkonsep dari penelitian yang relevan, namun demikian pembahasan dilakukan berbeda dengan pembahasan yang berbeda dengan penelitian-penelitian yang sebelumnya.

\section{METODE PENELITIAN}

Metode yang digunakan dalam penulisan artikel ini adalah literature review atau tinjauan pustaka. Riset pustaka tidak hanya sekedar urusan membaca dan mencatat literatur atau buku-buku sebagaimana yang sering dipahami banyak orang selama ini. Apa yang disebut dengan riset kepustakaan atau sering juga disebut dengan studi pustaka, ialah serangkaian kegiatan yang berkenaan dengan metode pengumpulan data pustaka, membaca, dan mencatat serta mengolah bahan penelitian (Zed 2008). Dalam penelitian ini penulis menggunakan model pendekatan content analysis. (kajian isi), penelitian ini bersifat pembahasan yang mendalam terhadap isi suatu informasi tertulis atau tercetak dalam media massa. Analisis ini biasanya digunakan pada penelitian kualitatif. content analysis (kajian isi) secara umum diartikan sebagai metode yang meliputi semua analisis mengenai isi teks, tetapi di sisi lain analisis isi juga digunakan untuk mendeskripsikan pendekatan analisis khusus, pada buku-buku sumber yang berkaitan dengan intervensi pada lembaga pendidikan.

\section{HASIL DAN PEMBAHASAN PENELITIAN}

Dari berbagai literatur ditemukan bahwa intervensi sebagai cara-cara yang patut digunakan dalam merencanakan perbtaikan berdasarkan pada masalah yang ditemukan dalam prses diagnosis dan pemberian umap balik. Intervensi berarti adalah keikutsertaan klein dan konsultan secara bersama-sama dalam upaya untuk merencanakan proses perbaikan berdasarkan atas masalah yang dijumpai dalam proses diagnosis(Thoha 2003).

Intervensi juga dapat dipahami sebagai tindakan yang dilakukan setelah proses diagnosa dilakukan, dan merupakan upaya solusi yang harus dilakukan setelah menemukan masalah dari proses diagnosa untuk kemudian merancang arah pengembangan organisasi yang diperlukan (Hardiyansyah dan Sumantri 2019). Intervensi juga diartikan sebagai aktivtas untuk melaksanakan rencana perubahan yang terencana yang dilakukan oleh pelaku perubahan (chage agent) terhadap berbagai sasaran perubahan (target of change) yang terdiri dari individu, keluarga, dan kelompok kecil (level mikro), komunitas dan organisasi (level mezzo) dan masyarakat yang lebih luas, baik ditingkat kabupaten/kota, provinsi, negara, maupun tingkat global (level makro) (Isbandi Rukminto Adi 2008).

Berdasarkan berbagai pendapat di atas maka dalam hal ini penulis mengambil kesimpulan bahwa intervensi pengembangan organsasi adalah serangkaian kegiatan secara terstruktur yang terdapat pada setiap unit organsasi dalam melaksanakan tugas secara langsung maupun tidak langsung yang dihubungkan dengan perbaikan organisasi.

Kemudian setelah kita memahami tentang apa itu intervensi, maka langkah selanjutanya adalah apa saja yang menjadi klasifikasi dari intervensi itu. Dalam hal ini Suharto membagi intervensi pada tiga bagian yaitu:

Intervensi mikro, intervensi mezzo dan intervensi makro (E. Suharto 2007). Hal ini dapat diuraikan sebagai berikut:

1. Intervensi mikro adalah keahlian pekerja sosial untuk mengatasi masalah yang dihadapi individu dan keluarga. Masalah sosial yang ditangani umumnya berkenaan dengan problema psiologis, seperti stres dan depresi, hambatan dengan relasi, penyesuaian diri, kurang percaya diri, keterasingan (kesepian). Metode utama yang biasa diterapkan oleh pekerja sosial dalam setting ini adalah terapi perseorangan (casework) yang didalamnya melibatkan berbagai teknik penyembuhan atau terapi psiososial seperti terapi berpusat pada klien (client-centered therapy), terapi perilaku (behavior therapy), dan terapi keluarga (family therapy). 
1546 Perilaku Dan Pengembangan Organisasi Pendidikan Review Disain Intervensi - Ulil Amri, Hendri, Rusdinal, Nurhizrah Gistituati

DOI: https://doi.org/10.31004/edukatif.v3i4.605

2. Intervensi mezzo dalam hal ini keahlian pekerja sosial adalah untuk mengatasi masalah yang dihadapi kelompok dan organisasi. Metode utama yang biasa diterapkan oleh pekerja sosial dalam setting mezzo ini adalah terapi kelompok (groupwork) yang didalamnya melibatan berbagai teknik penyembuhan seperti socialization group, self help group, recreatif group.

3. Intervensi makro adalah keahlian pekerja sosial untuk mengatasi masalah yang dihadapi komunitas, masyarakat dan lingkungannya (sistem sosialnya), seperti kemiskinan, ketelantaran, ketidakadilan sosial dan eksploitasi sosial. Adapun tiga metode utama dalam pendekatan makro adalah pengembangan masyarakat (comunity development), manajemen pelayanan kemanusiaan (human service management) dan analisis kebijakan sosial (social policy analysis).

Kemudian jika dilihat dari tatanan prakteknya intervensi ini juga dapat dibagi pada dua bentuk yaitu:

1. Praktik langsung ( Direct Practise) yaitu menyangkut pada aksi-aksi para indivudu, keluarga, maupun kelompok-kelompok kecil yang menfokuskan pada perubahan baik transaksi, sistem, dan fungsi dalam hubungan dengan orang atau institusi masyarakat yang ada dalam lingkungan mereka.

2. Praktik tingadk langsung (Inderect Practice), yaitu menyangkut pada aksi yang dilakukan degan orang lain (klein) supaya supaya menolong kliennya yang lain.(Jhonson 2001).

Setelah mengetahui tentang sasaran dari intervesi, maka agar intervensi tersebut juga dapat pahami secara baik, sengat diperlukan sekali bagaimana cara merencang intervensi dalam lembaga pendidikan, dalam hal ini membutuhkan tiga tahap dasar (Hardiyansyah dan Sumantri 2019): (1) Mengenali dan menghargai proses pembelajaran yang terjadi (2) melakukan gap antara pembelajaran yang sudah ada dengan kebutuhan strategi pembelajaran, (3) mengidentifikasi tindakan untuk meningkatkan keinginan kapabilitas pembelajaran.

Kemudian menurut Adi intervensi tersebut harus terencana dengan memiliki fase-fase tertentu yaitu:

1. Fase persipaan, dalam hal ini terdiri dari persiapan dalam pendataan, administrasi, serta kontak dengan klien.

2. Fase pengembangan kontak dengan klien, dalam hal ini dinilai adalah kekuatan dan kelemahan kelian, keberfungsian klien, motivasi klien dalam memecahkan masalah serta faktor lingkungan.

3. Fase pengumpulan data.

4. Fase perencanaan dan analisis, pada fase ini lakukan perencanaan yang akan dilakukan dan menganalisis permasalahan yang akan dihadapi,

5. Fase pelaksanaan yaitu melaksanakan apa yang seharusnya dilakukan yang sesuai dengan kontrak.

6. Fase Negosiasi.

7. Fase Terminasi (Isbandi Rukminto Adi 2008).

Rancangan intervensi yang baik, tentu saja akan intervensi yang efektif, dan interveksi yang efektif akan memperoleh hasil yang baik dalam sebuah pengembangan lembaga pendidikan. , tiga kriteria utama mendefinisikan intervensi yang efektif:

1. sejauh mana sesuai dengan kebutuhan organisasi;

2. gelar yang didasarkan pada pengetahuan kausal hasil yang diinginkan; dan

3. sejauh mana yang mentransfer kompetensi manajemen perubahan kepada anggota organisasi.(Tampubolon 2020)

Kriteria pertama menyangkut sejauh mana intervensi tersebut relevan dengan organisasi dan anggotanya. Intervensi yang efektif didasarkan pada informasi yang valid tentang fungsi organisasi; mereka memberi anggota organisasi peluang untuk membuat pilihan yang bebas dan terinformasi; dan mereka mendapatkan komitmen internal anggota untuk pilihan-pilihan itu.

Informasi yang valid adalah hasil dari diagnosis yang akurat dari fungsi organisasi.Itu harus mencerminkan secara adil apa yang dirasakan dan dirasakan anggota organisasi tentang primer mereka kekhawatiran dan masalah. Pilihan yang bebas dan terinformasi menunjukkan bahwa anggota terlibat secara 
1547 Perilaku Dan Pengembangan Organisasi Pendidikan Review Disain Intervensi - Ulil Amri, Hendri, Rusdinal, Nurhizrah Gistituati

DOI: https://doi.org/10.31004/edukatif.v3i4.605

aktif dalam membuat keputusan tentang perubahan yang akan mempengaruhi mereka. Prinsip ini juga berarti bahwa mereka dapat memilih untuk tidak berpartisipasi dan intervensi tersebut tidak akan dikenakan mereka.Komitmen internal berarti bahwa anggota organisasi menerima kepemilikan intervensi dan bertanggung jawab untuk mengimplementasikannya. Jika intervensi menghasilkan perubahan yang berarti, manajemen, staf, dan anggota terkait lainnya harus berkomitmen untuk melaksanakannya.

Kriteria kedua dari intervensi yang efektif melibatkan pengetahuan tentang hasil.Karena intervensi dimaksudkan untuk menghasilkan hasil yang spesifik, mereka harus didasarkan padapengetahuan yang valid bahwa hasil tersebut benar-benar dapat diproduksi. Kalau tidak adatidak ada dasar ilmiah untuk merancang intervensi OD yang efektif. Sayangnya - dan dalamberbeda dengan disiplin ilmu terapan lainnya, seperti kedokteran dan teknik - pengetahuanefek intervensi dalam tahap perkembangan yang belum sempurna di OD. Sebagian besarpenelitian evaluasi tidak memiliki ketelitian yang cukup untuk membuat kesimpulan kausal yang kuat tentangkeberhasilan atau kegagalan program perubahan

Kriteria ketiga dari intervensi efektif melibatkan sejauh mana itu meningkatkankapasitas organisasi untuk mengelola perubahan. Nilai-nilai yang mendasari OD menunjukkan bahwa berikut intervensi, anggota organisasi harus lebih mampu melaksanakan rencana mengubah aktivitas mereka sendiri. Dari partisipasi aktif dalam merancang dan mengimplementasikanintervensi, mereka harus mendapatkan pengetahuan dan keterampilan dalam mengelola perubahan. Kompetensidalam manajemen perubahan sangat penting dalam lingkungan saat ini, di mana teknologi, sosial,perubahan ekonomi, dan politik yang cepat dan gigih. Banyak organisasi, seperti Capital One, The Hartford, The Limited Brands, dan Microsoft, mengakui kebutuhan ini dansecara sistematis membangun kemampuan manajemen perubahan mereka

Konsisten dengan teori sistem seperti yang dijelaskan diatas, isu-isu organisasi saling terkiat dan harus terintegrasi satu sama lain. Organisasi harus mencocokan jawaban satu set pertanyaan dengan jawaban set lainnya, pertayaan untuk mencapai tingkat efektivitas yang tinggi. Misalnya, keputusan tentang mendapatkan keunggulan kompetitif harus sesuai dengan pilihan tentang struktur organisasi, menetapkan tujuan untuk dan orang -orang yang bermanfaat, komunikasi, pemecahan masalah. Intervensi yang disajikan dimaksud untuk mengatasi berbagai keprihatinan. Seperti yang ditunjukan dalam intervens, OD khususnya berlaku untuk isuisu spesifik. Dengan demikian desaian intervensi seyogyanya harus menciptakan metode perubahan yang sesuai dengan organisasi, serta juga masalah yang diidentifikan dalam diagnosis. Kemudian dari pada itu, karena masalah organisasi yang terkait bersama-sama, OD intervensi sama harus diintergrasikan dengan satu sama lainnya. Misalnya, intervensi penetapan tujuan yang mencoba untuk membangun memotivasi tujuan, maka diperlukan dintergrasikan dengan intervensi pendukung, seperti hadiah. Sistem yang menghubungkan membayar untuk pencapaian tujuan.

Kuncinya adalah berfikir dengan intervensi systemically yang ditujukan pada satu jenis masalah organisasi. Berfikir secara cermat tentang bagaiamana intervensi OD mempengaruhi berbagai jenis masalah dan bagaimana program perubahan yang berbeda mungkin diintegrasikan untuk membawa lebih luas dan lebih dampak kohenren pada fungsi organisasi adalah penting untuk intervesi yang efektif.

Penawaran dengan intervensi mengenai manajemen kinerja, termasuk program perubahan berikut:

1. Penentuan tujuan. Program perubahan ini melibatkan menetapkan tujuan yang jelas dan menantang. Saya berupaya untuk meningkatkan efetivitas organisasi dengan membentuklebih cocok antara tujuan pribadi dan organisasi. Manajer dan bawahan secara berkalabertemu untuk merencanakan pekerjaan, meninjau prestasi, dan memecahkan masalah dalam mencapai gol.

2. Penilaian kinerja. intervensi ini adalah proses sistematis bersama-sama menilai prestasi kerja terkait, kekuatan, dan kelemahan. Ini adalah utama intervensi manajemen sumber daya manusia untuk memberikan umpan balik kinerja untuk individu dan kelompok kerja. Penilaian kinerja merupakan penting hubungan antara penetapan tujuan dan sistem penghargaan. 
1548 Perilaku Dan Pengembangan Organisasi Pendidikan Review Disain Intervensi - Ulil Amri, Hendri, Rusdinal, Nurhizrah Gistituati

DOI: https://doi.org/10.31004/edukatif.v3i4.605

3. Sistem Reward. Intervensi ini melibatkan desain organisasi imbalan untuk meningkatkan kepuasan karyawan dan kinerja. Ini termasuk inovatif pendekatan untuk membayar, promosi, dan tunjangan.

4. Melibatkan masyarakat, intervensi ini menurut T. Suharto (2012) pendidikan melibatkan masyarakat hal ini sesuai dengan Undang-Undang Sistem Pendidikan Nasional 2003 yang mengungkapkan mengenai pendidikan berbasis masyarakat.

\section{KESIMPULAN}

Pengembangan organasisi merupakan suatu usaha perubahan perencanaan yang menekankan pada pada penerapan ilmu pengetahuan dan praktek prilaku untuk membantu organisasi mencapai efektifitas yang lebih besar. Dalam upaya pengembangan tersebut maka semua organinasi harus berubah karena adanya intervensi yang datang dari dalam lingkungan (internal) maupun yang datang dari luar (eskternal). Walaupun perubahan yang terjadi pada lingkungan, namun pada umunya perubahan lebih pada organiasisi. Intervensi yang baik tentu saja harus memperhatikan efektifitas yang dimunculkan dari intervensi sendiri, sehingga dengan adanya intervensi tersebut, maka organisasi bisa berubah kearah lebih baik, dalam mencapai tujuannya organsasi tersebut.

\section{UCAPAN TERIMA KASIH}

Penulis mengucapkan terima kasih pada pihak yang telah membantu suksesnya penelitian ini, terutama bapak Prof. Dr. Rusdinal, M.Pd. dan Ibu Prof. Dr. Nurhizrah Gistituati, M.Ed, selaku dosen pembimbing sehingga selesai makalah ini.

\section{DAFTAR PUSTAKA}

Anam, Ahmad Misbahul. 2018. "Intervensi Lembaga Dalam Menumbuhkan Partisipasi Masyarakat." Jurnal Bina Ummat: Membina dan Membentengi Ummat 1(02): 95-115.

Duha, Timotius. 2016. Perilaku Organisasi. Yogyakarta: Deepublish.

Hardiyansyah, Hardiyansyah, dan A. Sumantri. 2019. "Analisis Pengembangan Organisasi Pelayanan Publik melalui Proses Diagnosa dan Intervensi." Jurnal Ilmiah Administrasi Publik 5(1): 42-49.

Isbandi Rukminto Adi, I. 2008. Intervensi komunitas Pengembangan Masyarakat Sebagai Upaya Pemberdayaan MasyarakatNo Title. Jakarta: Rajagrafindo Persada.

Jhonson, L. 2001. Praktek Pekerjaan Sosial (Suatu Pendekatan Generalist). Bandung.

Johandri Taufan, Rika Maria, Rusdinal Rusdinal, Nurhizrah Gistituati. 2021. "Strategi Kepemimpinan Kepala Madrasah dalam Upaya Mewujudkan Madrasah Efektif." Edukatif: Jurnal Ilmu Pendidikan 3.

Latar, Bakroni. "Perubahan dan Pengembangan Organisasitle." Jurnal Literasi Pendidikan Nusantara 1.

Pramudyo, Gani Nur. "Intervensi Pengembangan Organisasi di Organisasi Pendidikan." https://www.ganipramudyo.web.id/2017/07/intervensi-pengembangan-organisasi-di.html.

Rifqi Muntaqo, A.Adibudin Al Halim. 2017. "Peningkatkan Mutu Pendidikan Melalui Budaya Organisasi Di Madrasah Aliyah Ali Maksum Yogyakarta.” Jurnal Pancar (Pendidik Anak Cerdas Dan Pintar) 01.

Suharto, Edi. 2007. Pekerja Sosial di Dunia Industri (Corporete Social Responsibility),. Bandung: Refika Adiutama.

Suharto, Tato. 2012. Pendidikan Berbasis Masyarakat Relasi Negera dan Masyarakat dalam Pendidikan. Yogyakarta: LKiS.

Tampubolon, Manahan P. 2020. Change Management Manajemen Perubahan: Individu, Tim Kerja Organisasi. 
1549 Perilaku Dan Pengembangan Organisasi Pendidikan Review Disain Intervensi - Ulil Amri, Hendri, Rusdinal, Nurhizrah Gistituati

DOI: https://doi.org/10.31004/edukatif.v3i4.605

Thoha, Miftah. 2003. Perilaku organisasi: konsep dasar dan aplikasinya. Jakarta: Grafindo Persada.

Wijaya, Candra. 2017. Lembaga Pengembangan Pendidikan Indonesia (LPPPI), Medan Perilaku individu organisasi. www.lpppindonesia.com.

Zed, Mestika. 2008. Metode Penelitian Kepustakaan. Jakarta: Yayasan Obor Indonesia. 